\title{
GABRIELLA INFINITA: A PERSPECTIVE OF COLOMBIAN HISTORY AND CULTURE THROUGH ELECTRONIC LITERATURE
}

\author{
Perla Sassón-Henry*
}

\begin{abstract}
Gabriella infinita is a landmark of Latin American digital literature by Colombian author Jaime Alejandro Rodríguez Ruiz. It is a hypermedia novel in Spanish which was originally written and published as a traditional printed novel in 1994, to later on become a hypertext and a hypermedia novel. As a literary piece, Gabriella Infinita is an excellent example of Latin American literature. It brings to the fore topics that have been common to many Latin American countries, such as a civil war, guerrilla wars, repression, freedom of expression, fear and exile. It also highlights Latin America fascination with the United States and the counterculture movements of the 1970s. This essay explores how Colombian writer Jaime Alejandro Rodríguez Ruiz uses the various modalities of the new media in his hypermedia Gabriella Infinita to provide a better understanding of Colombian culture and history.
\end{abstract}

KEYWORDS: Hypermedia. Electronic Literature. Colombia. War. Counterculture

\section{From Text to Virtual Worlds}

Gabriella Infinita evolved from a print version published in 1994 to a hypermedia version released in 2007. These changes were the result of the author's discovery of the term "hypertext" in 1997 as well as the author's realization that his multidimensional narrative called for a new and more appropriate medium of expression. The changes that have taken place have contributed to a better understanding of the novel, especially its characters and the situations in which they are immersed. It is this metamorphosis that this article seeks to highlight as well as the intrinsic value of this narrative as a powerful means to better understand some of the social and historical events of Colombian history which still are echoed in today's Colombian society and culture.

\section{Print Version}

\footnotetext{
* United States Naval Academy, Annapolis, Maryland, United States of America and Hermeneia Research Group. E-mail: sasson@usna.edu
}

\section{(cc) EY-NC-ND}

Esta obra está licenciada com uma Licença Creative Commons. 
Jaime Alejandro Rodríguez Ruiz is a sophisticated writer and avid user of digital technology as a tool to strengthen his narratives and their reach to vast audiences. Winner of the 2008 Award UCM - Microsoft Literaturas en Español del Texto al Hipermedia, Rodríguez Ruiz presents Gabriela Infinita in its website where he provides a thorough explanation of the metamorphosis the text has undergone since its inception. For those interested in this kind of "digital archeology," (GUTIERREZ 2007) Rodríguez Ruiz provides a chronological development of Gabriella Infinita. These transformations are clearly stated in the presentation page where the author refers readers to sections labeled: the novel, the book format, hypertext, hypertext structure, hypermedia and hypermedia characteristics. Each link serves as an important source of background information which is even more relevant to the novice hypermedia reader.

Gabriella Infinita is in its author's own words a "memory of a writing experience" (RODRÍGUEZ RUIZ, 2007). It was born out of an "intimate need of expression" that later on would lead to the "understanding that it is destined to volatility" (RODRÍGUEZ RUIZ, 2007). Gabriella Infinita is one more step in what the author calls "a literary exercise" (RODRÍGUEZ RUIZ, 2008-Presentation)

According to Rodríguez Ruiz, "[f]rom the canonical literary point of view, Gabriella Infinita (GI), the novel, is a fragmented story without explicit articulation, with an uncomfortable discursive heterogeneity, and with an excessive demand on the reader to participate. GI might not be a book, but it is a novel and the narrative solution was to put the story in the hipertextual format" (MARINO MARK, 2007 WRT).

The novel narrates multiple interwoven stories leading to the unraveling of events similar to the ones that took place in Colombia during la Violencia, a period of great political and social turmoil which affected the capital, Bogotá as well as many towns throughout the country. 
Federico Soler and Gabriella Ángel are two young lovers from Bogotá who are apart for unknown reasons. Gabriella has not seen Federico for six months. She is six months pregnant. She goes to Federico's apartment to pick up Federico's belongings and hopefully some clues which will help her come to terms with reality. War has moved from the mountains into the city making it even more difficult for Gabriella to come to terms with the unreality of her pregnancy and the new reality she is facing. It is up to reader to give closure to this story or series of stories.

In the same way that Gabriella must decode the clues she finds when she visits Federico's room, it is up to the reader to unveil the secrets of this hypermedia novel and its message.

The print version of the novel leads the reader to sections where the reader is immersed in historical, social and political events pertinent to Latin America and its desire for peace and freedom as expressed in the American flower movement of the 1970s. Right after this introduction to the novel the reader arrives at a section entitled Catástrofe ("Catastrophe") which is followed by Atrapados ("Trapped"). Both sections narrate the lives of the characters while trapped in a building after a bomb raid in Bogotá. Gabriella is isolated from the rest but in this solitude she finds a manuscript entitled El Guerrero ("The Warrior").

El Guerrero is in fact in the middle of the story. In a Borgesian style where the author challenges the reader to move back and forth in time, Rodríguez Ruiz introduces a flashback narrative that will resurface towards the end of the novel.

At this point other narrative threads are incorporated within the main story line. Threads suchs a Mujeres ("Women"), Domino ("Domino"), testimonies from witnesses and autobiographies add to this polyvocality/heteroglosia of expression. Nevertheless, the three main narratives converge at the end. Gabriella's findings in her search for Federico, the narratives of those trapped in the building and Federico's writing come 
together to unravel the author's witty argument that all that happened took place in Federico's manuscript.

Throughout the novel the reader encounters passages loaded with fear, desire for freedom, deception and hope. The author ends his narrative in a positive tone. Among the chaos of war Gabriella has given birth to a boy. Most of the city has been destroyed. The city has undergone the most devastating attack since 1948 year of the Bogotazo, an iconic event in Colombian history. While politicians leave the country most people struggle for survival amidst the contagious deceases that have spread throughout the city. The news reports that a baby has been rescued from the rubble. He was found surrounded by twelve adult corpses. He is a miracle and a symbol of hope for the city of Bogotá.

\section{Hypertext}

The hypertextual version of Gabriella Infinita which was developed between 1998-1999 showcases Rodríguez Ruiz's development and exploration with hypertext. The novel starts with an image of Gabriella and an epigraph. Once the reader clicks on the image or text, she arrives at a second screen where the reader could select which section of the novel she wishes to read. The reader is free to choose the thread she wishes to explore. Catástrofe, Atrapados, Guerrero, Mujeres, Voices, Federico and Dominoes are among the options. A few images accompany the narratives adding a new dimension to the interpretation of the stories.

Even though this version includes all the narrative included in the printed novel, it is quite probable that the reader might not read it all. Since the reader is allowed to move from one thread to another she will be recreating the narratives to produce a unique story which will lead to a very personal experience and interpretation of the literary work. Yet, the heterogeneity and volatility of the novel, its multiple plots, times as well as the digital developments of the time call for a new approach to Gabriella Infinita, one where 
the printed word, voice and structure enlighten each other to take Gabriella Infinita where the printed text could not.

\section{Hypermedia:}

Gabriella Infinita has taken digital literature and the use of technology for the understanding of literature and culture to a new frontier. It is this hypermedia version of Gabriella Infinita which will be the focus of this essay to illustrate the ways in which Gabriella Infinita contributes to a better understanding of Colombian history and culture. Following the terms used by Thea Pitman in her essay "Hypertext in Context: Space and Time in Latin American Hypertext and Hypermedia Fictions", one may very well say that representation of space, time, historical, social and political events are "embedded" in Gabriella Infinita.

As a fictional novel Gabriella Infinita immerses the reader in a series of events that relate to several historical, social and political incidents that took place during the last half of the twentieth century in Colombia. In spite of the fictional nature of this hypermedia novel there are some "autobiographical resonances" (RODRÍGUEZ RUIZ, 2014) and media that allows the reader to imagine and reflect upon those important landmarks in Colombian history.

A first reading of "Gabriella Infinita takes the reader back in time to recreate images of the infamous Bogotazo, which affected the lives of so many Colombians. On April 9, 1948 the socialist and influential politician Jorge Elicer Gaitán "was fatally shot" (PALACIOS, 2006, p. 141). His death stirred one of the most devastating events in Colombian history. Violent crowds took to the streets of Bogota like a "wave of popular fury" (PALACIOS, 2006, p. 141). As a result of months of pent up anger and disappointment with the government "agitated and (eventually) inebriated crowds that would later be known as the nueveabrileños or "April Niners" burned churches, trams, 
and public buildings" (PALACIOS, 2006, p. 142). By the end of the day thousands of people were dead mostly in the capital but also in other Colombian cities and towns.

The followers of Gaitán blamed the Bogotazo on "criminals who distorted the authentic grief of the people" (PALACIOS, 2006, p.142). The truth is that after the Bogotazo a new epoch of violence started in Colombia. Palacios characterizes the Violencia as "the outgrowth of hostility between Liberals and Conservatives" (2006, p.157).

In Gabriella Infinita the use of images and audio set the tone of this literary piece. The novel starts with an image which is reminiscent of the famous painting La Violencia (1962) by the Spanish artist Alejandro Obregón. In this painting Obregón depicts all the horror of a period known in Colombia as La Violencia. This period which the historian Marco Palacios encapsulates between 1945 and 1964 "justified a permanent state of siege, the constitutional weapon by the state to neutralize the mobilization of the urban masses whom the liberals had made their base" (PALACIOS, 2006, p. 135). It was a time when repression escalated to silent those against the regime. La Violencia still exists like a constant reminder of Colombia's past and present.

Jaime Alejandro Rodríguez Ruiz takes up the theme of Obregón's painting in a new way. The flickering abstract image of a fleeing pregnant woman whose body is covered in different shades of red serves as the portal to the stories the reader is about to unravel. Even though the abstract image refers to Gabriella it also suggests it could be any woman in Colombia trapped in a violent revolt or bomb attack in any town or city in Colombia. Her reddish body alludes to a bloody episode from which this woman attempts to escape. 
Fig. 1. Gabriella Infinita.

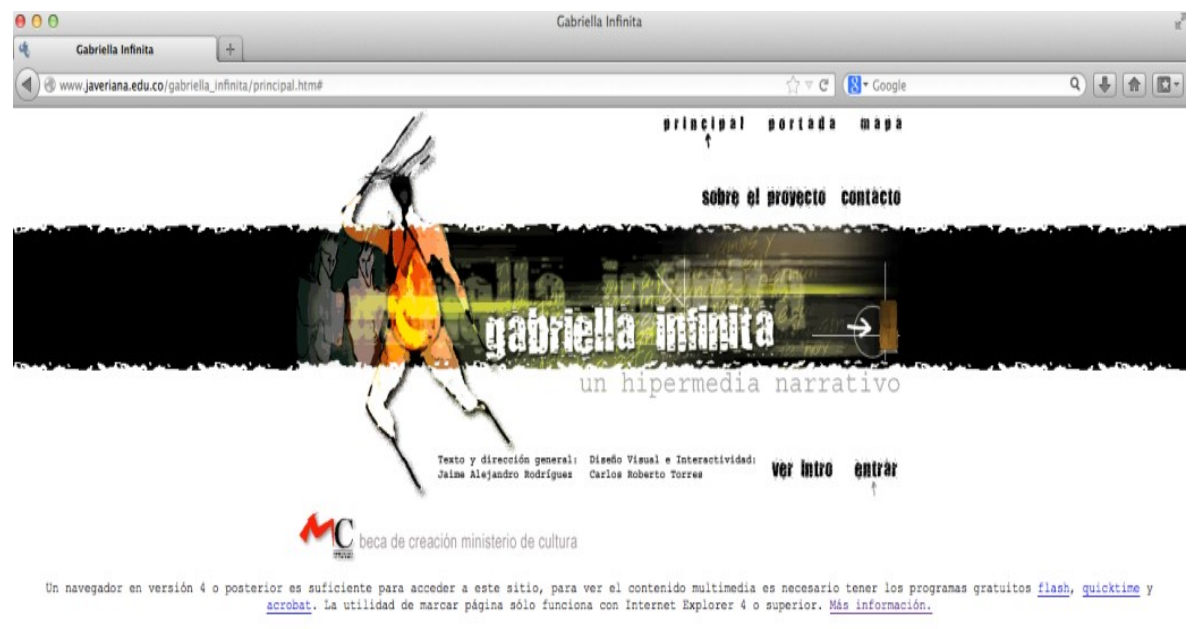

Graphic design and music supplement each other in a digital environment that suggests a rising tension as if anticipating a city at war. As a hypermedia novel Gabriella Infinita is the result of the close relationship between writer and the audiovisual designer. As Rodríguez Ruiz states in the introductory section of Gabriella Infinita entitled "Gabriella Infinita: las características del hypermedia," "la persona que coordinó y desarrolló todo lo relativo a la estructura y soluciones audiovisuales, se convirtió en un auténtico coautor de la obra. Fue ese diálogo entre escritor y creativo audiovisual, el que permitió obtener la solución actual" (2007). According to Rodríguez Ruiz "La música introduce sutilmente el ambiente de "guerra en la ciudad" que ambientará la narración" (2007). Though the geographical setting could very well refer the reader to any city in Colombia there is a strong suggestion that the city is Bogotá. Rodríguez Ruiz has made this explicit in the introduction to the hypermedia version. The banner behind each of the parts of the section Ruinas represents "la silueta de la ciudad de Bogotá" (2007). 
Fig. 2. Bogotá.

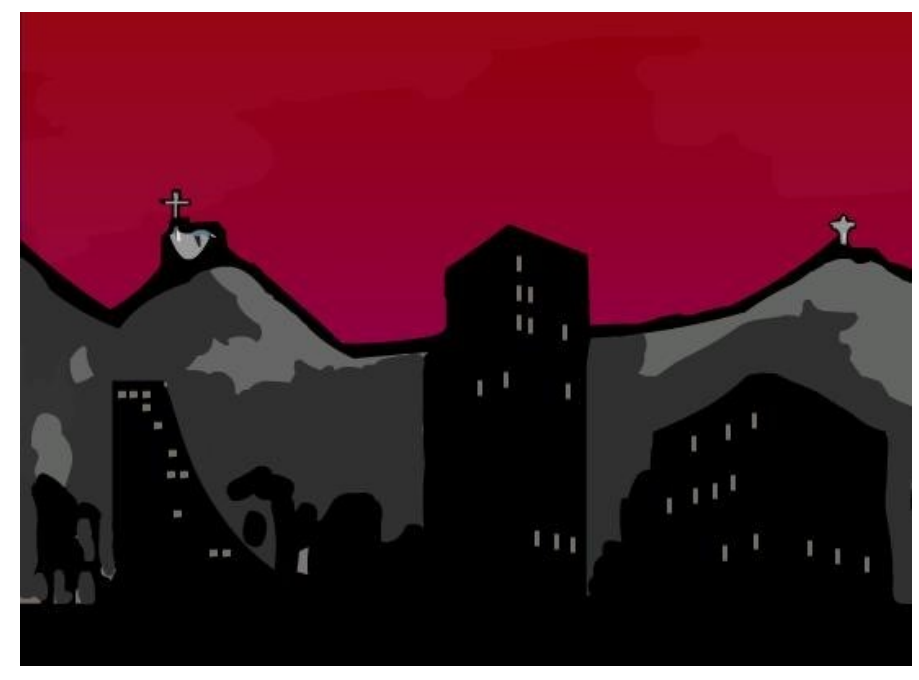

Once inside the texts of the sections entitled Ruinas the author gives us more descriptive clues about Gabriella's whereabouts in her search for Federico.

"Gabriella decidió seguir su camino. Avanzó por la Avenida Central hacia el sur y luego dobló por la Calle Diecinueve hacia las montañas. El paisaje de una ciudad, ahora desolada, no podía ser más aterrador. ...Al fondo, el Cerro Tutelar lucía calvo y envejecido." (Ruinas 2) ${ }^{1}$ Not only does the scene describe geographical features that approximate the reader to the city of Bogotá but it also presents the landscape of a city which has been devastated by a terrifying event. The continuity of the banner with the ruins of the city of Bogotá in all sections of Ruinas signals some type of continuity in the narration.

Gabriella's instinct led her to desperately cross a devastated city in search of Federico. She was determined to reach Federico's apartment:

Como si aún no hubiera despertado de su última pesadilla, Gabriella Ángel se encontró de pronto en medio del caos de unas calles repletas de automóviles abandonados y de gente que, intentando esquivar los latigazos que descargaban las ondas explosivas de las bombas, corría de un lado a otro enloquecida (Ruinas 1)

\footnotetext{
${ }^{1}$ The titles in parenthesis refer to the cited section of the hypermedia novel Gabriella Infinita.
} 
It is almost impossible to do a close reading of Gabriella Infinita without delving into the multiple historical and cultural references that immerse the reader in a period of time which was unique not only to Colombia but to the world where revolutionary and antiestablishment ideas had started to surface. Accounts of what happened during that time in Colombia have emerged from oral testimonials throughout the years. According to Palacios in the 1950 s these fragments "already provided the raw material for essays, novels, theatrical works, movies (a bit later), and works of visual art "(137). Throughout this hypermedia novel a combination of well-designed graphics, voice recordings and texts illustrate the main topics of this work, namely the political and social environment in Bogotá in the 1960s as well as the social and political movements that started circa 1958.

Even though the references to these events are subtlety interwoven throughout this novel, one of the key sections is Revelaciones. The original narratives were re-written and re-structured to make room for the voice recordings that substituted the original narratives. The multiple plots were re-organized to emphasize Gabriella's experience. The novel lost the "decentralized aspect of the three original stories" but it allowed for a deeper understanding of the situation from Gabriella and other witnesses' point of view (RODRÍGUEZ RUIZ, 2007).

It is in this section where Gabriella attempts to unveil the reasons for Federico's disappearance. It is also here where the reader almost as Gabriella's accomplice attempts to decode the various types of messages that Federico left in his apartment before he left. In a previous section entitled Mudanza Gabriella finds an assortment of Federico's belongings, among them a number of literary texts ranging from John Barth's "La casa encantada", some short stories by Jorge Luis Borges, a special edition of Julio Cortazar's "Casa tomada" and "El nombre de la Rosa" by Umberto Eco. Each of them provides Gabriella and the reader with some insights into Federico's somewhat reserved personality and disappearance.

Texto Digital, Florianópolis, Santa Catarina, Brasil, v. 11, n. 1, p. 46-64, jan./jun. 2015. ISSNe: 1807-9288. 
"Sí. Todo podía ser puesto en su lugar: los discos, las fotografías, los manuscritos, las cartas, las grabaciones, los libros, los videos, los recortes de periódico, todo podía ser ordenado y quién mejor que Gabriella para hacerlo, ella que había conocido a Federico, que había sufrido sus absurdos cambios de ánimo, sus ideas locas, ella que cargaba ahora un hijo suyo en el vientre. Un deber, era incluso un deber; no sólo el orden mismo de los materiales, sino el aporte que sus propios recuerdos, deseos y sentimientos pudieran hacer para resolver el misterio" ( Mudanza, carpeta).

As stated earlier Revelaciones provides the elements for Gabriella to unveil Federico's whereabouts, to question her own existence and to determine her own destiny.

In Federico's room Gabriella finds a binder entitled "INFORME DEL GUERRERO." As Gabriella reads the manuscript she questions her own existence. She cannot come to terms how the report of a man called Rickeman reached Federico's apartment. Rickeman was a schizophrenic man whom Gabriella and Federico visited some time before Federico's disappearance.

\footnotetext{
"Ahora, con el informe en sus manos, sin embargo, encontraba hechos, datos, circunstancias que no podrían ser explicados sino bajo la teoría del alibi. Si esto era cierto, jella misma podría ser ahora simplemente el producto de su imaginación!" ( Revelaciones, guerrero).
}

The report comments upon the level of idealism and romanticism reached by those who visited Rickman while he was institutionalized. It masterfully describes how the young revolutionaries were seen by the status quo.

"todos tan despistados como yo el primer día, quizás todos con los mismos problemas de memoria, porque sus rostros mostraban esa ingenuidad y esa "pureza" de quien se ha desprendido de los recuerdos y de los propósitos" ( Revelaciones, guerrero)

Sound and text are interwoven to unravel mysteries from Federico's life. The sound contributes to the tension and enigma created in the text. The bombings do not subside sound and text create an environment that suggests some sort of urgency. As Gabriella 
packs all she needs to return to her apartment she finds an essay which would give her a glimpse of the role of women in Federico's life. A draft entitled "Matilde arrepentida" encapsulates Federico's fascination with the nurturing role of women as mothers and wives. The same piece of writing also describes a woman's attempt to break free from her family in order to live life to the full. In Federico's writing a married woman called Elvira had unsuccessfully abandoned her home to explore her freedom. In her search she comes upon Matilde with whom she flees on her quest for adventure: "Durante días recorrieron caminos, visitaron pueblos, conocieron gente, se dedicaron a vivir" (Revelaciones, mujeres). As illustrated by the novel the love for her family forced Elvira to return to her home and her town only to find ruins and destruction: "Elvira entró a un pueblo, su pueblo, convertido en ruinas. Algún ataque del ejército o de la chusma, quien sabe, había arrasado el lugar" (Revelaciones, mujeres)

Elvira died in Matide's house and the secret she kept from her family stayed as a reminder of a violent past: "ella juró guardarse esta experiencia, sin saber que la amargura con que vivió por esa culpa secreta se filiaría genéticamente hasta marcar muchos de los comportamientos en nosotros, sus hijos; hijos también de la violencia" (Revelaciones, mujeres).

Once again as in many sections of the novel the topic of violence emerges in the narration. As illustrated by the above citations, Elvira lost almost everything on her idealistic search for freedom. Violence reached her town and family and it left a mark not only in Elvira's life but also in Matilde and her sons. The same text also alludes to the Women's Liberation movement and the feminist movement which were popular in the 1960s and which had repercussions in Latin America.

As Gabriella continues searching Federico's room she comes across some videotapes but there is one that specially catches her attention: it is entitled Dominoes. As the reader clicks on this icon she discovers the origin of the word Dominoes in relation to the political and social scene of the 1960s: 
Dominó, el juego que simboliza la manera como se movieron las fuerzas sociales en la década de los sesenta. Once jugadas, suficientes para agotar el juego: de un lado, las de la contracultura, de otro, las del estado opresor. La primera jugada: el derrumbe del sueño americano...

In this section the text informs the reader that Gabriella hears Federico's voice in the video which is supplemented by music and images of some of the most iconic events of the 1960s. The section is masterfully designed to narrate eleven sections that cover historical events that took place mainly in the United States throughout the 1960s. Among the topics mentioned are the famous documentary of the international concert Monterrey Pop, the Black Panthers, the Aquarius Era and the Vietnam experience without losing sight of the Flower Power movement, the phenomenon of drug consumption and the idyllic Woodstock concert. These were the issues that served as inspiration for Federico in his search for a new society. The narrator's comments inside the text serve exactly to describe the precision and thorough reflection in the assemblage of this section. Though the comments refer specifically to the Dominoes video, it can be very well applied to describe the way in which text, sound and image are articulated in this hypermedia novel:

Los comentarios de Federico complementaban las imágenes y las canciones con la reflexión. La combinación de las tres narrativas, producía el efecto de una perfecta crónica de los años sesenta. (Revelaciones, dominoes).

In Gabriella Infinita the text is supplemented by eleven brief music files that illustrate some of the most popular songs of the 1960s among them "The Thrill is Gone" by BBKing, "I heard it through the Grapevine" by Marvin Gaye, "Gimme shkelter" by the Rolling Stones", "Wild thing" by Jimmi Hendrix, "Summertime" by Janis Joplin and "Freedom" by Richie Havenns. These songs transport the reader to Federico's social and political life to give him a glimpse of the motives that could have led to his disappearance. As portrayed by the images and sounds the section also highlights the beginning of the counterculture movement in the United States, President Kennedy's 
assassination as well as the beginning of the Free Speech Movements. There is also a reference to events that are akin to Federico and Gabriella's lives. One of the most important events mentioned in the novel is the student movements that started in Paris in 1968 and their repercussion throughout the world. The role of students throughout the world and how the student demonstrations around the world affected the lives of those who had an active participation in the counterculture movements that emerged from the universities are significant to this close reading of Gabriella Infinita. These episodes are relevant because Federico was a university professor who was immersed in the counterculture movement of his time.

Es el turno para los estudiantes en todo el mundo: el movimiento 22 de marzo en París, disturbios en Berlín, la Zengakuren y el movimiento Zokio en Japón, la masacre de Tlatelolco en México, los incidentes aquí en Bogotá y en Bucaramanga. Surgen las figuras: Federico Cohn Bendit en Nanterre, Rudy Dutsche en Alemania, Vittorio Riesser en Italia. Se levantan barricadas, explota la ira y la cólera contenidas, la imaginación produce las más bellas consignas, se recurre a nuevos símbolos: Cuba, el Che Guevara. Es el llamado a resistir, a parar el mundo, que ahora se respira globalmente.

In many of the cases above political protests ended in violence and deaths inflicted by the government. The section ends up with a somewhat somber sense of disillusionment: political activists are under the attach of the police and/or the armed forces, rock becomes a product for the masses, drugs are altered to destroy those who consume them but above the sense of utopia and social revolution is no longer possible, all that is left is individual resistance. In Gabriella Infinita all these ideas are conveyed not only by the written word but by the song "Find the cost of freedom" by Crosby, Still and Nash which seems to declaim the end of an era.

As we can see the richness of the novel goes beyond its poetic language and superb narrative to immerse the reader in a vast array of historical, cultural and political 
information that allows the reader to create a better understanding of some of the origins of the social instability and violence that permeated in Colombian history.

There is no doubt that in Revelaciones Jaime Alejandro Rodriguez Ruiz plays with the reader and challenges her not only to gather information on Federico but to assemble the historical puzzle of Colombian history. Once Gabriella finds the cassettes that Federico left behind, the reader unveils the lives and philosophy of five of Federico's friends: Lucas, Fajardo, Guillermo, Eduardo and Molano. Their recordings are permeated with references to their experiences and memories of songs from the Hispanic world that addressed the dreams of a generation. The speeches of the five men are so realistic in content and in tone that the listener is immersed in a vivid account of the social and political milieu of Colombia in the 1970s and 1980s. In his recording Fajardo talks about life in Colombia in the seventies and eighties and refers to them as the decades of the imagination and war respectively. His speech provides a detailed description of squads which would break into and raid people's homes in the middle of the night. Fajardo believes that the eighties is a decade of an undeclared war, a time of conformism and a bureaucratic and parasitic society. He succinctly describes his generation as a generation of death and of the missing.

It is also in this section where there is a clear reference to Camilo Torres Restrepo a Catholic priest, university professor and social activist who motivated by his radical views decided to join the guerrilla group National Liberation Movement. In Gabriella Infinita Camilo Torres is remembered for his great influence among university students many of which died in "wildly dangerous missions whose alleged purpose was to temper them for combat, the most famous case being Camilo Torres Restrepo, 'the revolutionary priest' who died in his first armed conflict with the army, only weeks after joining the ELN" ( PALACIOS, 2006, p. 192).

As Gabriella continues her search in Federico's room she wonders whether Federico wanted to leave some kind of message. She cannot come to terms with the fact that all 
she has found so far is just a mere coincidence. An icon with a diskette leads the reader to unfold details of Federico's past, his family ties with the government, his military ancestors, his involvement with the guerrilla movement and his return to the city after the death of his comrades. His return to the city is also marked by a feeling of guilt as he finds out that members of his family have been victims of a dirty war. He reflects whether he has been the cause of those deaths.

No sólo se fue p'al monte el día que el gobierno promulgó su temerario estatuto de seguridad, sino que comió mierda y aprendió a usar el M-15 y respetó con estoicismo una jerarquía tan dura que la vida en familia (por donde todo comenzó) resultaba un juego de niños. No sólo estuvo listo para el asalto (hasta el día que supo de la muerte de su amigo), sino que creyó ver en ese compromiso el advenimiento de un nuevo mundo, un nuevo hombre. ( Revelaciones, semblanza)

An icon illustrated with printed computer pages takes the reader to a section where Gabriella acknowledges that all the time she has spent in Federico's apartment has not been in vain. Gabriella has found Federico's manuscripts. She believes she is giving birth to two creatures: One that comes from her own being and another that stems from Federico's writing. From that section the reader moves to the actual icon with Federico's writing where he develops a type of memoir in which he acknowledges his bitterness, rancor and dissatisfaction with himself. He acknowledges that his country is involved in a violent war:

Cómo no admitir, por ejemplo, que mi coqueteo con el "poder estudiantil" en la universidad no había sido más que una caricatura grotesca o que mi espíritu pusilánime pesó más que mi sensibilidad social en el momento en que tuve la única oportunidad de permanecer en la guerrilla; en fin, cómo no confesar que mi vida, a los treinta años de edad, era una completa mierda.

Sí, es cierto: ahora era todo un catedrático respetable... Pero en un país que deja morir a su gente de abandono en las calles, en un país que quiere embarcarse en una guerra absurda, eso no era suficiente. Había que hacer algo distinto. (Revelaciones, catastrofe) 
The last icon to appear in Revelaciones resembles a film script. The film narrates a war in Colombia and a city like Bogotá where a group of friends including a pregnant Gabriella and Federico struggle during the last minutes of their lives. The bombing continues, the building is coming down upon them, one of the character's voices narrates the action of a guerrilla group in the Colombian jungle, a proud sense of courage for what he has done as a warrior. As the building collapses the guerrilla warrior dies. The last scene of the script describes a scene where all characters have succumbed to the power of bombs. Their death is imminent. The tone is somber: "No vemos a Federico ni al niño...Tampoco Gabriella se encuentra en la escena... A lo mejor ya habita su realidad otra... ( Revelaciones, atrapados).

As it has been shown Revelaciones is a key section of this hypermedia novel. The superb use of text, image and audio interwoven in the novel provide not only the plot to the story but also most of the historical background to understand the social and political situation in Colombia in the 1960s, 1970s and 1980s. What is even more outstanding is the use of narratives within narratives that serve as stories in their own terms or to provide information to further understand not only the historical context but the gist of the main story which is Gabriella's quest for Federico which develops throughout the novel as Gabriella's raison de être.

Jaime Alejandro Rodríguez Ruiz digital venture in Gabriella Infinita goes beyond the plot and/or plots present in this hipermedia novel. Rodríguez Ruiz lures digital readers to pursue and develop new techniques for reading and understanding literature. Readers can track, save and print their readings. One of the most creative and interesting sections from the narratological perspective is the fact that all the sections in Gabriella Infinita have an icon entitled escribe tu historia ( write your story) which directs readers to a blog where they can reflect and comment on the events described in the novel. By doing this Rodríguez Ruiz sets the Latin American digital literary social network in motion. Throughout history literature has always led to discussion and debate, in this case Rodríguez Ruiz has created a digital venue in the form of a blog where readers 
can express their opinions and reflections taking into account their own experiences in reference to the violent, volatile and chaotic Colombia from the 1960s, 1970s and 1980s. The blog also allows readers to explore their creativity by trying to describe Federico in their own words. The result of this exercise resulted in a hundred and thirteen comments whereby readers have defined Federico according to their own terms based on their reading and personal experiences. This type of activity is especially innovative taking into account that in this case the blog acts as a sort of social network and forum of debate.

Parallel to this narratological development, there is a theoretical approach that Rodríguez Ruiz has relied upon to develop his hypermedia novel. The theoretical foundation of Gabriella Infinita stems from the ideas as presented in Rodríguez Ruiz's book El Relato Digital hacia un nuevo arte narrativo (2006,) which is also available on line.

Gabriella Infinita conveys the author's portrayal of the volatile, chaotic and violent history of Colombia. From a technological perspective Gabriella Infinita showcases the technological developments available to writers and readers from the 1980s until the time the piece was published on line. Gabriella Infinita underscores the relevance of the remediation processes which make possible new modes of expression and, thus allows for different approaches to understanding literature. Whereas the printed version allows for multiple narratives which take the reader back and forth in time, the hypermedia version with its voice recordings, music and visuals adds a new dimension to the narrative.

Gabriella Infinita is a truly Latin American narrative. Even though the topics developed may be pertinent to Colombia, they can also be applied to other Latin American countries where political violence has manifested in different ways at different points in history. Past, present and future converge in a narrative that desperately seeks peace As a hypermedia novel Gabriella Infinita masterfully lures readers to approach reading 
literature from a new perspective that encompasses the inclusion of text, video and sound. At the same time Gabriella Infinita offers a plethora of political, social and historical references that allow readers to engage in a better understanding of some of the social and cultural events that took place in Colombia and that led to the creation of this novel. Above all at a time when the world's peace seems to be in peril and Colombia desperately seeks peace Gabriella Infinita concludes with a message of hope: a newly born baby has been found among the rubble in a city which has been completely devastated by bombs.

\section{GABRIELLA INFINITA: UMA PERSPECTIVA DA HISTÓRIA E DA CULTURA DA COLÔMBIA ATRAVÉS DA LITERATURA ELETRÔNICA}

RESUMO: Gabriella Infinita é um marco da literatura latino-americana digital do autor colombiano Jaime Alejandro Rodríguez Ruiz. É um "romance hipermídia" em espanhol que foi originalmente escrito e publicado como um romance tradicional, impresso em 1994, para mais tarde se tornar um hipertexto e um romance hipermídia. Como uma peça literária, Gabriella Infinita é um excelente exemplo de literatura latino-americana. Ela traz à tona os assuntos que têm sido comuns a muitos países latino-americanos, tais como uma guerra civil, conflitos de guerrilha, repressão, liberdade de expressão, medo e exílio. Também destaca o fascínio da América Latina com os Estados Unidos e os movimentos de contracultura da década de 1970. Este ensaio explora como o escritor colombiano Jaime Alejandro Rodríguez Ruiz usa as várias modalidades das novas mídias em seu hipermídia Gabriella Infinita para fornecer uma melhor compreensão da cultura e da história colombiana.

PALAVRAS-CHAVE: Hipermídia. Literatura Eletrônica. Colômbia. Guerra. Contracultura.

\section{References}

GUTIÉRREZ, Juan B. "Literatronic" 2007. Last access November 7, 2014. URL: $<$ http://www.literatronica.net/src/Nuntius.aspx?lng=BRITANNIA\&nuntius=OPUS_ABOUT _1\&opus=1>.

PALACIOS, Marco. 2006. Between Legitimacy and Violence: A History of Colombia between 1875-2002.Durham: Duke University Press.

MARINO MARK. Interview with Jaime Alejandro Rodríguez Ruiz. WRT: Writer Response Theory, 2007. Last access November 7, 2014. URL:

<http://writerresponsetheory.org/wordpress/2007/05/10/interview-with-jaime-alejandrorodriguez-ruiz/>. 
PITMAN, Thea. 2007. Hypertext in Context: Space and Time in Latin American Hypertext and Hypermedia Fictions. Dichtung- Digital. Last access November 7, 2014. URL: <http://www.dichtung-digital.org/2007/Pitman/pitman.htm>.

RODRÍGUEZ RUIZ, Jaime. Personal interview via Facebook messanger. 2014.

, 2007. Gabriella Infinita. Last access November 7, 2014. URL:

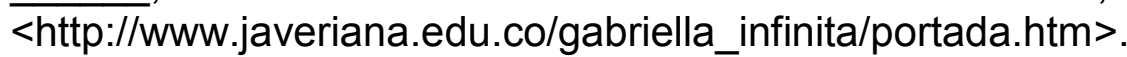

, 2006. El Relato Digital hacia un nuevo arte narrativo. Last access

November 7, 2014. URL: <http://www.scribd.com/doc/23242364/El-relato-digital-haciaun-nuevo-arte-narrativo>.

Texto recebido em: 10/07/2015.

Texto aceito em: 28/07/2015. 